\title{
Pengaruh TATO, DER, ROE, PER terhadap harga saham pada sektor barang konsumsi BEI Tahun 2016-2018
}

\author{
Natalia; Nina Purnasari*; Ratnawaty Lumbantoruan; Etnasius Waruwu
}

Program Studi Akuntansi Fakultas Ekonomi Universitas Prima Indonesia

*E-mail korespodensi: ninaunpri@gmail.com

\begin{abstract}
The study was conducted to test how it affects partial independent variables and is simultaneous with bound variables. Where the free variables are Total Asset Turn Over(TATO), Debt To Equity Ratio(DER), Return On Equity(ROE), Price Earning Ratio(PER), and which become variables dependent is the Stock Price. The study had 52 populations while the sample consisted of 34 companies in 3 periods of consumer goods companies, So the total amount of data over three years was 102. In the visible TTest results, a conclusion can be drawn that partially shows TATO and DER have no effect and no significance to the Stock Price. Where the variables ROE and PER have an influence and significant impact on the Stock Price. Then following the results of the $F$ test, it can be concluded TATO, DER, ROE, and PER there is an influential and significant simultaneous on the Stock Price. The research was tried by the procedure of multiple linear regression methods and the test hypothesis using the Spss 23 process.
\end{abstract}

Keywords: TATO, DER, ROE, PER, Stock price

\begin{abstract}
Abstrak
Kajian ini dilakukan dengan bertujuan menguji bagaimana pengaruhnya antara variabel independen yang parsial dan simultan dengan variabel terikat. dimana variabel bebasnya ialah Total Asset Turn Over(TATO), Debt To Equity Ratio(DER), Return On Equity(ROE), Price Earning Ratio(PER) dan yang menjadi variabel dependen adalah Harga Saham. Penelitian ini memiliki 52 populasi sedangkan sampel terdiri dari 34 perusahaan pada 3 periode perusahaan barang konsumsi, sehingga jumlah data secara keseluruhan selama 3 tahun adalah 102. Pada hasil Uji T yang terlihat, maka bisa ditarik sebuah simpulan yang menunjukkan secara parsial TATO dan DER tidak terdapat pengaruhnya dan tidak terdapat signifikannya pada Harga Saham. Dimana variabel ROE dan PER terdapat pengaruhnya dan signifikannya pada Harga Saham. Kemudian sesuai dengan hasil yang terlihat pada Uji F, bisa disimpulkan TATO, DER, ROE dan PER terdapat pengaruhnya serta signifikannya yang simultan pada Harga Saham. Penelitian dicoba dengan tata cara metode regresi linear berganda serta hipotesis uji memakai proses Spss 23.
\end{abstract}

\footnotetext{
Kata kunci : TATO, DER, ROE, PER, Harga saham

PENDAHULUAN

Industri barang konsumsi ialah salah satu bagian yang memiliki peranan berarti dalam memicu perkembangan ekonomi Negara. Dimana salah satu dari bagian industri barang konsumsi yaitu subsektor industri makanan dan minuman yang masih mendominasi serta menyumbang emiten terbanyak pada sektor manufaktur, ialah berjumlah 26 emiten. Tidak heran, bila subsektor industri makanan dan minuman ini menjadi tumpuan serta memberikan kontribusi terbanyak dalam perkembangan sektor perusahaan manufaktur di Indonesia. Tidak cuma itu saja, subsektor industri makanan dan minuman juga mempunyai kontribusi signifikan terhadap perkembangan ekonomi.
} 
Saham ialah dokumen berharga yang menampilkan kepemilikan suatu perusahaan. Membeli saham mengartikan jika sudah mempunyai hak kepemilikan atas suatu perusahaan. Harga saham ialah nilai saat ini dari arus kas yang hendak diterima oleh owner saham di masa depan. Semakin mahal harga saham artinya semakin baik nilai perusahaan . Naik serta menurunnya harga saham bakal terikat dengan naik serta turunnya nilai perusahaan di mata pasar secara universal.

Buat mengukur hingga seberapa besar efektivitas perusahaan memakai sumber daya berbentuk pemakaian aset serta semakin cepat balik dana dalam wujud kas. Total Asset Turnover sendiri ialah rasio penjualan dan total aktiva yang mengukur efisiensi pemakaian aktiva secara totalitas.

Semakin besar proporsi Debt to Equity Ratio berdampak keuntungan perusahaan tidak menentu serta menaikkan kemungkinan kalau perusahaan tidak bisa penuhi kewajiban pelunasan utang. Semakin besar Return On Equity berarti semakin efisiensi serta efektif perusahaan memakai ekuitasnya, serta kesimpulannya keyakinan investor atas modal yang ditanamkannya di perusahaan lebih baik dan bisa berikan pengaruh positif untuk harga saham di pasar. Semakin besar Price Earning Ratio investor semakin yakin pada emiten, sehingga harga saham terus menjadi mahal serta Price Earning Ratio mempengaruhi positif terhadap harga saham.

Berdasarkan penelitian terdahulu yang dilakukan Haque (2013) dengan judul Impact of Fundamental Factors on Stock Price. Hasil penelitian menyimpulkanbahwa harga saham tidak memiliki hubungan yang signifikan dengan fundamental perusahaan. Hasil dari studi tersebut menunjukkan bahwa EPS, DPS, TATO, ROA dan ROE tidak berpengaruh signifikan terhadap harga saham.

Penelitian terdahulu oleh Ermaya \& Nugraha(2018)menemukan hasil penelitian yang sama bahwa TATO memiliki hubungan negatif dan signifikan terhadap harga saham pada perusahaan Industri Barang Konsumsi yang terdaftar di BEI periode 20142015. Penelitian yang dilakukan oleh Firmansyah (2017) pada Perusahaan Manufaktur di BEI periode 2010 sampai dengan 2014 menemukan hasil yang sama bahwa TATO tidak berpengaruh signifikan terhadap Harga Saham. Nugraha \& Sudaryanto (2016) juga menemukan hasil yang sama dalam penelitiannya pada Perusahaan Industri Dasar dan Kimia yang terdaftar di BEI yang menemukan bahwa TATO tidak memiliki pengaruh yang signifikan terhadap harga saham perusahaan.

Penelitian terdahulu oleh Puspita (2013) pengaruh Current Ratio (CR), Net Profit Margin (NPM), Return on Assets (ROA), Debt to Equity Ratio (DER), Total Assets Turnover (TATO), dan Earning per Share (EPS) terhadap Harga Saham. Kesimpulan bahwa dari hasil uji-t dari variabel CR, NPM, ROA, DER, TATO dan EPS hanya variabel CR, NPM, DER, dan TATO yang berpengaruh signifikan terhadap Harga saham. Lalu berdasarkan hasil uji-F, maka diketahui bahwa CR, NPM, ROA, DER TATO dan EPS dinyatakan berpengaruh terhadap harga saham.

Penelitian terdahulu oleh Asri \& Indarti (2011) Pengaruh Net Profit Margin (NPM), Return on Assets (ROA) dan Return on Equity (ROE) Terhadap Harga Saham. Kesimpulan bahwa dari hasil uji -t, variabel NPM dan ROA tidak berpengaruh signifikan terhadap harga saham sedangkan ROE berpengaruh signifikan terhadap harga saham. Lalu berdasarkan hasil uji-F, maka diketahui bahwa NPM, ROA, dan ROE secara simultan mempunyai pengaruh siginifikan terhadap harga

Penelitian terdahulu oleh Fitri (2016) meneliti tentang Pengaruh Kinerja Keuangan Terhadap Harga Saham Perusahaan Food And Beverage Di BEI. Hasil penelitian menyimpulkan bahwa variabel PER, ROE, DER, TATO dan CR berpengaruh tidak signifikan terhadap harga saham, sedangkan variabel ROE berpengaruh signifikan terhadap harga saham.

Penelitian terdahulu oleh Bassey (2016) menemukan hasil bahwa PER berpengaruh positif signifikan terhadap harga saham pada perusahaan minyak dan gas 
di Bursa Efek Nigeria sesuai dengan pendapat Astuty (2017) yang juga menemukan pengaruh positif PER terhadap harga saham. Penelitian dengan hasil yang berbeda dilakukan Lestari \& Suryantini (2019) juga menemukan hasil bahwa PER berpengaruh negatif dan signifikan terhadap harga saham perusahaan Farmasi di BEI. Hasil penelitian yang dilakukan Warrad(2017) menemukan hasil bahwa PER tidak berpengaruh signifikan terhadap harga saham pada bank di Jordania.

\section{METODE}

Populasi ialah wilayah generalisasi yang terdiri atas: obyek/subyek yang mempunyai kualitas dan karakteristik tertentu yang ditetapkan oleh peneliti untuk dipelajari dan kemudian ditarik kesimpulannya (Sugiyono, 2017:80). Teknik pengambilan sampel menggunakan purposive sampling. Populasi terdiri dari 52 perusahaan yang terdaftar di BEI. Jumlah sampel penelitian sebanyak 102 selama tahun 2016-2018.

\section{HASIL DAN PEMBAHASAN}

\section{Statistik deskriptif}

Dalam melaksanakan pengujian ini, memakai 34 sample $(\mathrm{N})$ perusahaan sektor barang konsumsi dalam kurun waktu selama 3 periode, mulai dari tahun 2016-2018 dengan total keseluruhan data penelitian ini ialah berjumlah 102 data. Berikut tabel statistik deskriptif pada pengolahan data sampel.

Tabel 1. Statistik deskriptif

\begin{tabular}{llllll}
\hline & N & Minimum & Maximum & Mean & Std. Deviation \\
\hline TATO(X1) & 102 &, 06 & 3,10 & 1,0752 &, 58141 \\
DER(X2) & 102 &, 08 & 2,65 &, 7698 &, 57902 \\
ROE (X3) & 102 &, 00 & 2,24 &, 2250 &, 36830 \\
PER (X4) & 102 &, 01 & 207,94 & 17,6189 & 35,61717 \\
HG (Y) & 102 & 87,00 & 83800,00 & 6232,6667 & 15111,78225 \\
Valid N (listwise) & 102 & & & & \\
\hline
\end{tabular}

Sumber: Data diolah, 2020

Variabel TATO (X1) mempunyai nilai paling rendah senilai 0,06 , terdapat pada PT. Inti Agri Resources Tbk (IIKP) tahun 2017, nilai paling tinggi ialah senilai 3,10 tertera di PT. Wilmar Cahaya Indonesia Tbk (CEKA) tahun 2018, untuk nilai rataratanya ialah senilai 1,0752, dengan standar deviasi sebesar 0,58141. sementara itu

Variabel DER (X2) mempunyai nilai paling rendah ialah senilai 0,08 terdapat pada PT. Inti Agri Resources Tbk (IIKP) tahun 2017, nilai paling tinggi ialah senilai 2,65 yang tertera di PT.Unilever Indonesia Tbk (UNVR) tahun 2017 dan sedangkan untuk nilai rata-ratanya ialah senilai 0,7698 , untuk nilai standar deviasinya adalah 0,57902 .

Kemudian untuk ROE(X3) mempunyai nilai paling rendah senilai 0,00 yang tertera di PT.Kedaung Indah Can Tbk (KICI) tahun 2016 dan PT. Martina Berto Tbk (MBTO) tahun 2016 juga, nilai paling tinggi ialah senilai 2,24 terdapat pada PT. Merck Tbk (MERK) tahun 2018 dan sedangkan untuk nilai rata-ratanya ialah senilai 0,2250. Kemudian untuk standar deviasinya adalah 0,36830 .

Kemudian untuk PER (X4) mempunyai nilai paling rendah 0,01 terdapat pada PT. Martina Berto Tbk (MBTO) tahun 2018, nilai paling tinggi ialah 207,94 yang tertera di 
PT. Gudang Garam Tbk (GGRM) tahun 2017 sedangkan untuk nilai rata-ratanya ialah 17,6189 dengan standar deviasi sebesar 35,61717. serta variabel Y (HG) mempunyai nilai paling rendah senilai 87,00 yang tertera di PT. Budi Starch \& Sweetener Tbk (BUDI) tahun 2016, untuk nilai paling tinggi ialah senilai 83800,00 yang tertera di PT. Gudang Garam Tbk (GGRM) pada 2017 dan sedangkan untuk rata-ratanya ialah senilai 6232,6667 dimana standar deviasinya sebesar 15111,78225.

\section{Hasil uji asumsi klasik}

\section{Uji normalitas}

Dalam hal ini, Gambar 1 memperlihatkan hasil kurva cenderung besar mengikuti kurva normal dan garis.kurva yang condong berbentuk simetris dengan demikian menunjukkan bahwa data telah memenuhi asumsi dari pengujian normalitas dan dinyatakan bahwa sebaran data terdistribusi normal.

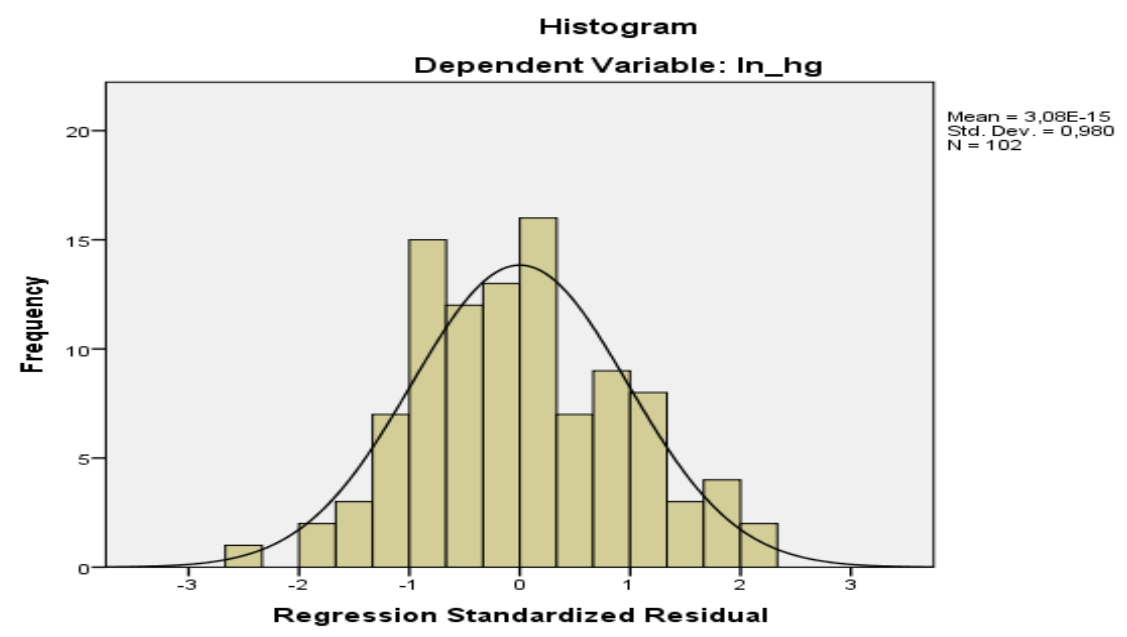

Sumber: Data diolah, 2020

Gambar 1. Grafik histogram

Berdasarkan hasil output SPSS Grafik Normalitas P-P Plot Pada Gambar 2, dapat dilihat bahwa gambar titik-titik pada P-P Plot terlihat mengikuti dan mendekati garis diagonalnya dapat disimpulkan bahwa data telah berdistribusi normal.

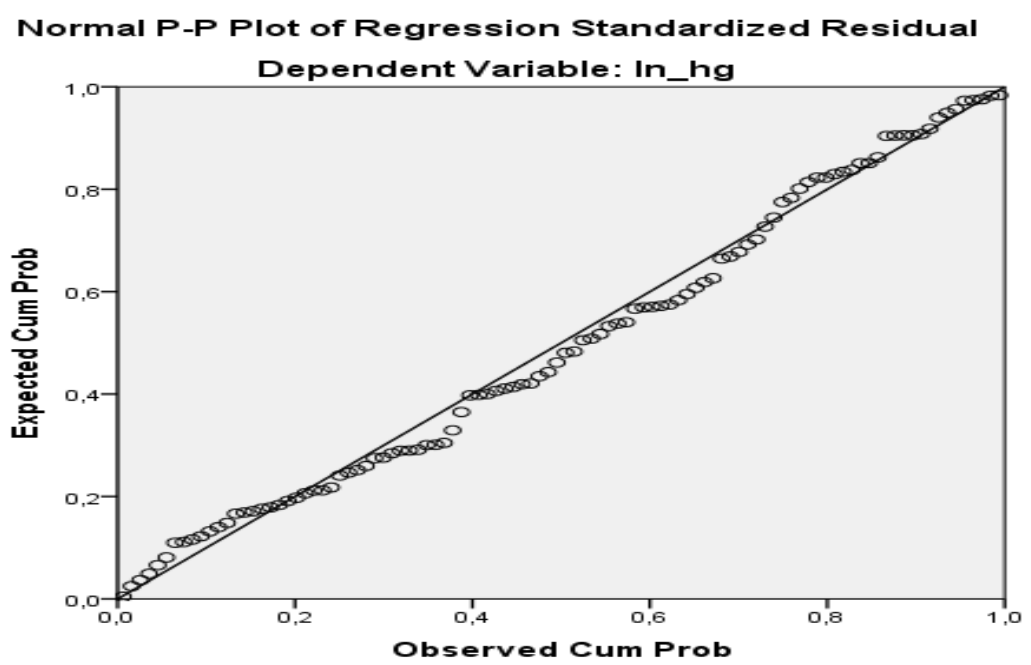

Sumber: Data diolah, 2020

Gambar 2. Normal P-P plot of regression 
Hasil uji normalitas Kolmogorov Smirnov menunjukkan nilai signifikan 0,200 > 0,05 dimana dapat dikonklusikan bahwa data telah berdistribusi secara normal.

Tabel 2 Uji kolmogrov smirnov setelah transformasi

\begin{tabular}{llr}
\hline & & Unstandardized residual \\
\hline $\mathrm{N}$ & & 102 \\
Normal Parameters & Mean &, 0000000 \\
& Std. Deviation &, 89813994 \\
Most Extreme & Absolute &, 072 \\
Differences & Positive &, 072 \\
& Negative &,- 046 \\
Test Statistic & &, 072 \\
Asymp. Sig. (2-tailed) & &, $200^{\mathrm{c}, \mathrm{d}}$ \\
\hline
\end{tabular}

Sumber: Data diolah, 2020

Berdasarkan Table 3 terlihat nilai toleransi TATO, DER, ROE, PER dan Harga Saham setelah ditransformasi $>0,10$, kemudian untuk VIF nya sendiri ketika sudah dilakukan nya transfomasi <10. Maka dari itu, bisa dikatakan bahwa hasil dari pengujian Multikolonieritas ini tidak terjadinya regresi diantara Variabel Independennya

Tabel 3. Uji multikolonieritas

\begin{tabular}{llc}
\hline \multirow{2}{*}{ Model } & \multicolumn{2}{c}{ Collinearity statistics } \\
\cline { 2 - 3 } & Tolerance & VIF \\
\hline (Constant) & & \\
ln_tato &, 845 & 1,183 \\
ln_der &, 956 & 1,046 \\
ln_roe &, 772 & 1,295 \\
ln_per &, 807 & 1,240 \\
\hline
\end{tabular}

Sumber: Data diolah, 2020

Dari pengujian Durbin-Watson memperlihatkan bahwa nilainya adalah 2,082; kemudian pada tabel DW sendiri dimana " $\mathrm{k} "=4$ (variabel bebas, tidak termasuk variabel terikat) dan $\mathrm{N}=102$ besar dari nilai dl (batas bawah) =1,5969 dan du $($ batas atas $)=1,7596 ; 4-\mathrm{dl}=2,4031$ dan $4-\mathrm{du}=2,2404$. Oleh karena itu berdasarkan pada tinjauan kriteria yang terdapat pada acuan yang ada di dalam DurbinWatson menjelaskan nilai dari $\mathrm{du}<\mathrm{dw}<4-\mathrm{du}$ atau 1,7596<2,082<2,2404.

Tabel 4. Uji autokorelasi

\begin{tabular}{cccccc}
\hline Model & R & R Square & $\begin{array}{c}\text { Adjusted R } \\
\text { Square }\end{array}$ & $\begin{array}{c}\text { Std. Error of } \\
\text { the Estimate }\end{array}$ & $\begin{array}{c}\text { Durbin- } \\
\text { Watson }\end{array}$ \\
\hline 1 &, $854^{\mathrm{a}}$ &, 729 &, 718 &, 91647 & 2,082
\end{tabular}

Sumber: Data diolah, 2020

\section{Uji heterokedastisitas}

Pada gambar di bawah memperlihatkan titik titiknya teersebar dengan tidak terkumpul dalam satu tempat yang sama.maka dapat ditarik simpulan bahwa tidak ada terjadinya heterokedastisitas. 


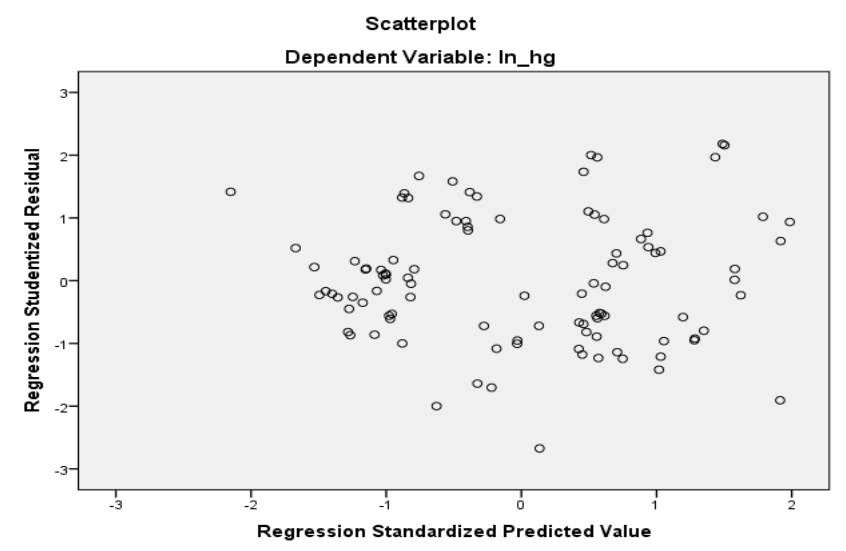

Gambar 3. Grafik Scatterplot

Untuk hasil Persamaan Regresi Linear Berganda maka bisa diambil suatu simpulan bahwa Konstanta @ menunjukkan bahwa Variabel ini Terdiri atas ln_tato,ln_der, ln_roe, dan ln_per dengan demikian maka ln_hg sebesar 8,020.

Tabel 5. Hasil Uji Regresi Linear Berganda

\begin{tabular}{|c|c|c|c|c|c|c|}
\hline & \multirow[t]{2}{*}{ Model } & \multicolumn{2}{|c|}{$\begin{array}{l}\text { Unstandardized } \\
\text { Coefficients }\end{array}$} & \multirow{2}{*}{$\begin{array}{c}\begin{array}{c}\text { Standardized } \\
\text { Coefficients }\end{array} \\
\text { Beta } \\
\end{array}$} & \multirow[t]{2}{*}{$\mathbf{t}$} & \multirow[t]{2}{*}{ Sig. } \\
\hline & & $\mathbf{B}$ & Std. Error & & & \\
\hline \multirow[t]{5}{*}{1} & (Constant) & 8,020 & 218 & & 36,794 &, 000 \\
\hline & ln_tato & , 178 & , 145 & ,071 & 1,226 & ,223 \\
\hline & ln_der &, 051 & ,113 &, 025 & , 455 & ,650 \\
\hline & ln_roe & ,528 & ,085 & ,372 & 6,190 & ,000 \\
\hline & ln_per & ,424 & ,041 & 610 & 10,363 & ,000 \\
\hline
\end{tabular}

Sumber: Data diolah, 2020

\section{LN_Harga saham $=8,020+0,178$ LN_Total Asset Turn Over+0,051 LN_Debt to Equity Ratio+0,528 LN_Return On Equity +0,424 LN_Price Earning Ratio}

Persamaan ini memperlihatkan bahwa terjadinya peningkatan ln_tato sebanyak $1 \%$, maka dari itu memicu terjadinya peningkatan $\ln \_$hg sebanyak $0,178 \%$. ln_der meningkat sebanyak $1 \%$, maka dari itu membuat ln_hg meningkat sebanyak $0,051 \%$. ln_roe meningkat sebanyak $1 \%$, maka dari itu membuat $\mathrm{ln}$ _hg meningkat dengan nilai $0, \overline{5} 28 \%$. serta $\ln \_$per juga meningkat sebanyak $1 \%$, sehingga membuat ln_hg meningkat $0,424 \%$

Tabel 6. Koefisien determinasi $\left(R^{2}\right)$

\begin{tabular}{llllll}
\hline Model & R & R Square & $\begin{array}{l}\text { Adjusted } \\
\text { Square }\end{array}$ & R & $\begin{array}{l}\text { Std. Error of } \\
\text { Estimate }\end{array}$ \\
\hline 1. &, $854^{\mathrm{a}}$ &, 729 &, 718 &, 91647 \\
\hline
\end{tabular}

Sumber: Data diolah, 2020

Tabel 6 yang tertera memperlihatkan hasil dari pengujian determinasinya, dimana Adjusted $\mathrm{R}$ square menunjukkan nilai sejumlah 0,718. Artinya bahwa Harga Saham atau variabel dependen ini akan dijelaskan TATO,DER,ROE dan PER sebagai variabel independen yakni sebanyak $71,8 \%$. Kemudian untuk sisanya sendiri sebanyak 
28,2\% diterangkan pada Variabel Independen yang berhubungan dengan variabel ini, yang terdapat di luar dari Penelitian.

Tabel 7. Uji F (simultan)

\begin{tabular}{llrrrrr}
\hline & Model & \multicolumn{1}{c}{$\begin{array}{c}\text { Sum of } \\
\text { Squares }\end{array}$} & Df & Mean Square & \multicolumn{1}{c}{ F } & \multicolumn{1}{c}{ Sig. } \\
\hline 1 & Regression & 219,171 & 4 & 54,793 & 65,236 &, $000^{\mathrm{b}}$ \\
& Residual & 81,472 & 97 &, 840 & & \\
Total & 300,643 & 101 & & & \\
\hline
\end{tabular}

Sumber: Data diolah, 2020

Dari Tabel 7 memperlihatkan hasil uji $F_{\text {hitung }}$ senilai 65,236.pada $F_{\text {tabel }}=\mathrm{k}$; n-k $(4 ; 102-4)=(4 ; 98)$, jadi nilai $F_{\text {tabel }}$ pada taraf kepercayaan 0,05 senilai 2,46 , dengan demikian nilai $F_{\text {hitung }}=65,236>F_{\text {tabel }}=2,46$ dimana nilai signifikasinya ialah 0,000 . Hal demikian memperlihatkan bahwa $H_{a}$ dapat diterima, yang artinya Tato, Der, Roe, Per secara simultan terdapat pengaruhnya dan signifikannya pada harga saham.

Tabel 8. Uji t (parsial)

\begin{tabular}{|c|c|c|c|c|c|}
\hline \multirow{2}{*}{ Model } & \multicolumn{2}{|c|}{ Unstandardized coefficients } & \multirow{2}{*}{$\begin{array}{c}\begin{array}{c}\text { Standardized } \\
\text { coefficients }\end{array} \\
\text { Beta } \\
\end{array}$} & \multirow[t]{2}{*}{$\mathbf{t}$} & \multirow{2}{*}{ Sig. } \\
\hline & B & Std.Error & & & \\
\hline (Constant) & 8,020 &, 218 & & 36,794 & ,000 \\
\hline ln_tato & ,178 & , 145 & ,071 & 1,226 & ,223 \\
\hline ln_der & 051 & 113 & 025 &, 455 & 650 \\
\hline ln_roe & ,528 & ,085 & ,372 & 6,190 & ,000 \\
\hline ln_per & ,424 & ,041 & ,610 & 10,363 &, 000 \\
\hline
\end{tabular}

Sumber: Data diolah, 2020

Dari pengujian Tabel 8 , meperlihatkan pada $t_{\text {tabel }}=(\alpha / 2 ; \mathrm{n}-\mathrm{k}-1)=(0,05 / 2 ; 102-4-$ $1)=(0,025 ; 97)$. Untuk nilai distribusi pada $t_{\text {tabel }}$ sendiri ditemukan nilai sebesar 1,98472 .

Untuk hasilnya sendiri dari perhitungan TATO terhadap harga saham terdapat $t_{\text {hitung }}$ senilai 1,226 , sedangkan $t_{\text {tabel }}$ senilai 1,98472 yang dapat dinyatakan $t_{\text {hitung }}<$ $t_{\text {tabel }}$ atau $1,226<1,98472$. nilai signifikan senilai 0,223 yang menyatakan nilai signifikan $>0,05$, untuk itu bisa ditarik sebuah simpulan bahwasanya Tato tidak terdapat pengaruh dan tidak signifikan pada harga saham.

Untuk hasilnya sendiri dari perhitungan DER terhadap harga saham terdapat pada $t_{\text {hitung }}$ senilai 0,455 , sedangkan $t_{\text {tabel }}$ senilai 1,98472 yang dapat dinyatakan $t_{\text {hitung }}<t_{\text {tabel }}$ atau $0,455<1,98472$. nilai signifikan senilai 0,650 yang menyatakan tingkat signifikasinya $>0,05$. Makanya dengan itu, bisa diambil sebuah simpulan bahwasanya DER tidak terdapat pengaruhnya dan juga tidak ada signifikasinya pada Harga Saham.

Untuk hasilnya sendiri dari perhitungan ROE terhadap harga saham terdapat $t_{\text {hitung }}$ senilai 6,190 sedangkan $t_{\text {tabel }}$ senilai 1,98472 yang dapat dinyatakan $t_{\text {hitung }}>t_{\text {tabel }}$ atau 6,190>1,98472. Nilai signifikan senilai 0,000 yang menyatakan tingkat signifikannya sendiri $<0,05$. Untuk itu, bisa ditarik sebuah simpulan bahwasanya ROE terdapat pengaruhnya dan signifikannya pada harga saham. 
Untuk hasil perhitungannya PER terhadap harga saham terdapat $t_{\text {hitung }}$ senilai 10,363 sedangkan $t_{\text {tabel }}$ senilai 1,98472 yang dapat dinyatakan $t_{\text {hitung }} t_{\text {tabel }}$ atau 10,363>1,98472. nilai signifikannya senilai 0,000 dan menyatakan tingkat signifikannya $<0,05$. Untuk itu bisa ditarik sebuah simpulan bahwasanya PER terdapat pengaruhnya dan signifikannya pada harga saham.

\section{Pengaruh total asset turn over terhadap harga saham}

Untuk hasil penganalisisan data secara parsial memperlihatkan bahwasanya $t_{\text {hitung }}<t_{\text {tabel }}$ atau 1,226<1,98472, nilai dari signifikannya senilai 0,223 $>0,05$. Untuk itu $H_{1}$ ditolak, dimana pada hasil dari penelitian memperlihatkan TATO tidak mempunyai pengaruh pada "harga saham dalam perusahaan manufaktur" sektor barang konsumsi yang terdapat di BEI tahun 2016-2018". Hasil dari riset ini tidak sejalan dengan hasil yang pernah di teliti Hanafi dan Halim (2005:83) yang memperlihatkan bahwa adanya pengaruh yang positif pada harga saham.

\section{Pengaruh debt to equity ratio terhadap harga saham}

Untuk hasilnya dari penganalisisan data secara parsial memperlihatkan nilai dari $t_{\text {hitung }<} t_{\text {tabel }}$ atau 0,455<1,98472. Kemudian nilai signifikannya senilai 0,650 $>0,05$. Untuk itu, $H_{2}$ ditolak, sebab hasil dari penelitian memperlihatkan DER tidak mempunyai "pengaruh pada harga saham dalam perusahaan manufaktur sektor barang konsumsi yang terdapat di BEI tahun 2016-2018".

Dengan demikian, pada penelitiannya ini sejalan pada hasil yang pernah diteliti Husnan dan Pudjiastuti (2015:70) "yang memperlihatkan bahwasanya DER tidak mempengaruhi perubahan harga saham pada suatu perusahaan".

\section{Pengaruh return on equity terhadap harga saham}

Pada hasil penganalisisan data secara parsial memperlihatkan nilai dari $t_{\text {hitung }} t_{\text {tabel }}$ atau 6,190>1,98472, nilai dari signifikannya ialah 0,000<0,05. Untuk itu, $H_{3}$ diterima karena hasil penelitian memperlihatkan bahwa ROE mempunyai pengaruh pada harga saham dalam perusahaan manufaktur sektor barang konsumsi yang terdapat di BEI 2016-2018".

Oleh karena itu, penelitiannya ini sejalan juga pada hasil yang pernah diteliti Fahmi (2014:183) apabila semakin besarnya nilai dari ROE maka tinggi juga harga saham. Karena pemasukan yang akan diperoleh owner perusahaan bakal semakin meningkat sehingga harga saham pada perusahaannya juga bertambah, artinya bahwa ROE terdapat pengaruhnya pada hagra saham.

\section{Pengaruh price earning ratio terhadap harga saham}

Pada penganalisisisan data tersebut, maka secara parsial bisa memperlihatkan nilai dari $t_{\text {hitung }} t_{\text {tabel }}$ atau 10,363 $>1,98472$ Untuk nilai signifikannya senilai $0,000<0,05$. Untuk itu $\mathrm{H}_{4}$ diterima karena hasil yang ditunjukkan pada penelitian memperlihatkan PER mempunyai "pengaruh pada harga saham dalam perusahaan manufaktur sektor barang konsumsi yang terdapat di BEI 2016-2018".

Dengan demikian, penelitiannya ini sejalan dengan hasil yang pernah diteliti Tandelilin (200:191) dimana semakin besarnya PER menampilkan prospek harga saham sebuah perusahaan dapat di nilai besar penanam modal pada penghasilan per lembarnya saham. Sehingga PER yang makin besar menampilkan semakin mahalnya harga saham tersebut terhadap pendapatannya. 


\section{KESIMPULAN DAN SARAN}

\section{Kesimpulan}

Total Asset Turnover ( X1) tidak mempengaruhi harga saham di industri manufaktur bagian barang konsumsi di BEI tahun 2016- 2018. Debt Equity Ratio ( X2) tidak memiliki pengaruh dengan harga saham di industri manufaktur bagian barang konsumsi di BEI tahun 2016- 2018. Return on Equity (X3) memiliki pengaruh terhadap harga saham pada perusahaan manufaktur bagian barang konsumsi di BEI tahun 20162018.

Price Earning Ratio (X4) memiliki pengaruh terhadap harga saham pada perusahaan industri manufaktur bagian barang konsumsi di BEI tahun 2016- 2018. Total Asset Turnover, Debt Equity Ratio, Return on Equity, serta Price Earning Ratio secara simultan mempengaruhi harga saham perusahaan manufaktur bagian barang konsumsi di BEI tahun 2016- 2018. Sebab tingkatan nilai $<0,05$ dan nilai $F_{\text {hitung }}>F_{\text {tabel. }}$

\section{Saran}

Menurut hasil penelitian dapat disarankan oleh pengkaji sebagai berikut: 1) Bagi Perusahaan, riset ini dapat berguna untuk pihak manajemen perusahaan jadi masukan buat tingkatkan kinerja perusahaan, dilihat melalui rasio keuangan yang baik menampilkan prospek bagus bagi perusahaan di masa depan dan menarik investor memberikan dana di perusahaan. 2) Bagi Peneliti Selanjutnya, riset ini bisa untuk menambah referensi yang dipelajari khususnya mengenai pengaruh Total Asset Turnover, Debt Equity Ratio, Return on Equity, serta Price Earning Ratio terhadap harga saham.

\section{DAFTAR PUSTAKA}

Astuty, P. (2017). The Influence of fundamental factors and systematic risk to stock prices on companies listed in the Indonesian Stock Exchange. European Research Studies Journal, 19 (4A), 230-240.

Bassey, B. E. (2016). Effect of corporate earnings on stock price of selected oil and gas companies in the Nigerian. European Journal of Business and Innovation Research, 4(5), 93-111.

Darmadji,Fakhrudin. (2015). Pasar modal di Indonesia. Ed.3, Salemba Empat: Jakarta

Dini, Astri W., and Iin Indarti. (2011). Pengaruh net profit margin (NPM), return on assets (ROA) dan return on equity (ROE) terhadap harga saham yang terdaftar dalam indeks emiten LQ45 Tahun 2008 - 2010.Jurnal Kajian Akuntansi dan Bisnis, 1(1), 1-18

Ermaya, S. K., \& Nugraha. (2018). Pengaruh current ratio, debt to equity ratio, total assets turnover dan earning per share terhadap harga saham. Jurnal AKP, 8(1), 51-78.

Fahmi,Irfan.(2016). Pengantar manajemen keuangan teori dan soal jawab. Cetakan Kelima. Alfaberta: Bandung

Fitri, S. A. 2016. Pengaruh kinerja keuangan terhadap harga saham perusahaan food and beverages di BEI. Jurnal Ilmu dan Riset Manajemen. 5(4).

Ghojali. (2006). Aplikasi analisis multivariate dengan program SPSS. Badan Penerbit Universitas Diponegoro: Semarang

Haque, S. (2013). Impact of fundamental factors on stock price. International Journal of Business and Management Invention. 2(9).34-41 
Hery.(2015). Analisis laporan keuangan pendekatan rasio keuangan. Cetakan Pertama. CAPS: Yogyakarta

Kasmir. (2015). Analisis laporan keuangan. Cetakan Kedelapan. PTRaja Grafindo Persada: Jakarta

Lestari, I. S. D., \& Suryantini, N. P. S. (2019). Pengaruh CR, DER, ROA, dan PER terhadap harga saham pada perusahaan farmasi di BEI. E-Jurnal Manajemen Fakultas Ekonomi dan Bisnis Universitas Udayana, 8 (3), 1844-1871.

Muawwanah,Risalatul. (2016). Pengaruh variabel fundamental dan volume perdagangan terhadap return saham(studi kasus pada industri makanan dan minuman tahun 2010- 2014):Skripsi.Fakultas Ekonomi dan Manajemen UIN Maulana Malik Ibrahim:Malang.

Nugraha, R. D., \& Sudaryanto, B. (2016). Analisis pengaruh DPR, DER, ROE, dan TATO terhadap harga saham (studi kasus pada perusahaan industri dasar dan kimia yang terdaftar di BEI periode 2010-2014). Diponegoro Journal of Management, 5(4), 1-12.

Sartono,Agus. (2012). Manajemen keuangan. Ed.4, BPFE: Yogyakarta

Sugiyono.2016. Metode Penelitian kualitatif, Kuantitatif dan R\&D. Ed.Baru, Alfaberta: Bandung

Wahyudiono. (2014). Mudah membaca laporan keuangan. raih asa sukses, 2014.

Warrad, L. H. (2017). The effect of marke valuation measures on stock price: an empirical investigation on jordanian banks. International Journal of Business and Social Science, 8 (3), 67-74. 